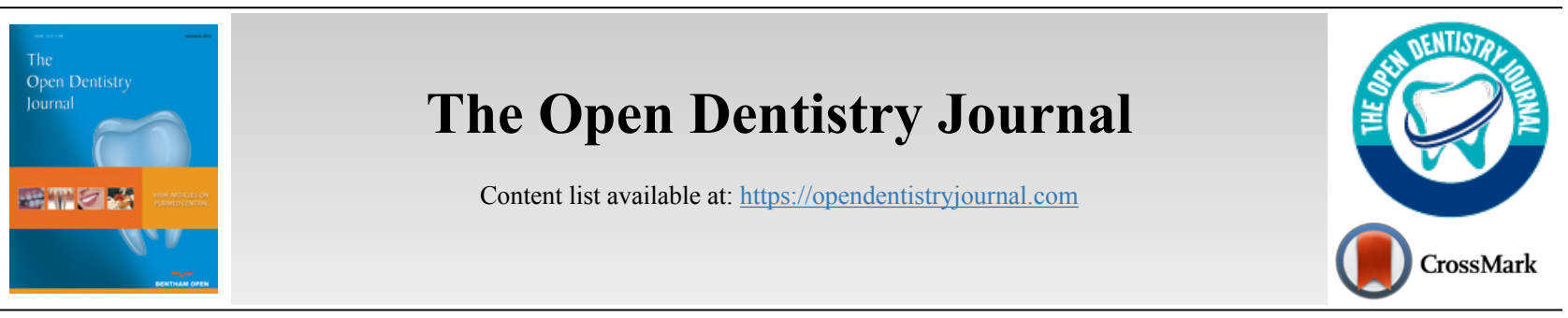

\title{
LETTER
}

\section{Immunosuppressive Effect of Mesenchymal Stromal Cells is Enhanced by IL-1a from Oral Squamous Cell Carcinoma Cells}

Hiroe Morimoto-Ito ${ }^{1,2}$, Masako Mizuno-Kamiya ${ }^{2}$, Naoki Umemura ${ }^{1}$, Yoshinori Inagaki ${ }^{3}$, Eiji Takayama $^{1}$, Harumi $\mathrm{Kawaki}^{1}$, Yasunori Muramatsu ${ }^{4}$, Shinichiro Sumitomo ${ }^{4}$ and Nobuo Kondoh ${ }^{1, *}$

${ }^{1}$ Department of Oral Biochemistry, Division of Oral Structure, Function and Development, Asahi University School of Dentistry, $1851-1$ Hozumi, Mizuho, Gifu, 501-0296, Japan

${ }^{2}$ Chemistry Laboratory, Department of Business Administration, Asahi University School of Business Administration, 1851-1 Hozumi, Mizuho, Gifu 501-0296, Japan

${ }^{3}$ Department of Anesthesiology, Division of Oral Pathogenesis and Disease Control, Asahi University School of Dentistry, 1851-1 Hozumi, Mizuho, Gifu, 501-0296, Japan

${ }^{4}$ Department of Oral and Maxillofacial Surgery, Division of Oral Pathogenesis and Disease Control, Asahi University School of Dentistry, 1851-1 Hozumi, Mizuho, Gifu, 501-0296, Japan

\begin{abstract}
:
Background:

We have already reported that mouse Oral Squamous Carcinoma Cells (OSCCs) Sq-1979 specifically enhance the immunosuppressive activity of mesenchymal 10T1/2 cells via the functional soluble factor (s).

Objective:

In this report, we attempted to identify soluble factor(s) mediating the immunosuppression of Sq-1979 cells.

Methods:

L5-11 cells are a variant established from the metastatic lymph nodes of Sq-1979-implanted mice. Unlike parental Sq-1979 cells, however, L5-11 cells lack promotion of immunosuppressive activity in 10T1/2 cells. In order to identify cytokine mRNAs specifically expressed in Sq-1979 cells but not in L5-11 cells, cDNA microarray was performed. Conditioned medium from Sq-1979 cells (CM) was absorbed by several different neutralizing antibodies (abs) against the corresponding cytokines. The absorbed CM was then co-cultured with 10T1/2 cells and anti-CD3 antibody-stimulated mouse spleen cells. The Interferon (IFN) $-\gamma$ producing capability of the stimulated spleen cells was evaluated using EnzymeLinked Immunosorbent Assay (ELISA). By using a specific cytokine product instead of CM in this co-culture system the source of the immunosuppressive effect was identified.

Results:

The expression of $C c l 2, C c l 7, I l 1-\alpha, I L 1 f 6$ and $I l 6$ mRNAs was specifically elevated in Sq-1979 cells compared to L5-11 cells. The suppression of the IFN- $\gamma$ producing capability of stimulated spleen cells in the co-culture system was specifically alleviated by absorbing the CM with anti-IL-1 $\alpha$ ab. We further demonstrated that the immunosuppressive effect of CM in the co-culture system could be completely substituted by IL-1 $\alpha$ protein $(50 \mathrm{pmol} / \mathrm{ml})$.

Conclusion:

The immunosuppressive function of 10T1/2 cells is specifically promoted by IL- $1 \alpha$, secreted by Sq-1979 cells.
\end{abstract}

Keywords: OSCC, Mesenchymal stromal cell, Spleen cell, Immunosuppression, IL-1 $\alpha$, IFN- $\gamma$.

\begin{tabular}{|c|c|c|c|}
\hline Article History & Received: February 28, 2019 & Revised: April 23, 2019 & Accepted: May 23, 2019 \\
\hline
\end{tabular}

\section{INTRODUCTION}

OSCC is the most common malignant tumor of the oral cavity [1]. The disease has historically had a poor prognosis, with a low overall survival rate of about $60 \%$ [2] attributed to recurrence and cervical lymph node metastasis. Yet despite its 
prevalence and severity, the 5 year survival rate has not been improved for the past 30 years [3]. The onset of OSCC has also been linked to chronic inflammation resulting from periodontitis. Research has suggested that chronic infection of resident microbiota $P$. gingivalis activates enzymatic cascades enhancing cellular invasion by OSCCs [4]. The progression and malignancy of tumors, including oral squamous cell carcinoma (OSCC), is regulated by the biological influences of tumor micro environments (TME) surrounding the tumor tissue that affect the host's immunological response [5 - 7]. Several lines of evidence have demonstrated that stromal cells surrounding tumor cells play important roles in developing progressive phenotypes of tumor tissues. In head and neck cancers, cancer associated fibroblasts (CAFs) have been suggested to promote angiogenesis, invasion and Treg induction via several cytokines including IL-6, CCL2, CCL7, TGF- $\beta 1$ and TNF- $\alpha$ [8]. CAF-educated macrophage progenitor cells reduce $\mathrm{T}$ cell proliferation via TGF- $\beta 1$, IL-10 and ARG1, suggesting that CAFs can induce protumoral TumorAssociated Macrophages (TAMs) in the immunosuppressive microenvironment [9]. In OSCC tissues, CAFs are divided into 3 grades on the basis of the expression of alpha smooth muscle actin, with the CAFs in the highest grade promoting CD163 positive macrophages, which are associated with poor prognosis [10]. Constitutive production of IL-1 $\alpha$ from OSCCs enhances IL-6 production of CAFs [11]. IL-6 and GM-CSF, produced by pancreatic CAFs, are important mediators of Myeloid Derived Suppressor Cell (MDSC) differentiation [12].

In the TME, infiltration of $\mathrm{CD} 8^{+} \mathrm{T}$ cells is an indicator for good prognostic criterion [13]. We have already reported that the regulatory mechanism of antitumor immunity mediated by Th1 cytokine, IFN- $\gamma$, is drastically changed among the mice implanted with primary versus advanced variants of the OSCC cells [14]. Our results further suggest that the immunosuppressive function of mesenchymal stromal cells is specifically enhanced by humoral factor(s) from primary OSCC cells [15], which, however, do not induce any MDSCs in the tumor-bearing mice [16]. In contrast, in the advanced OSCC-bearing mice, MDSCs could possibly be a major conductor of immunosuppression [16]. Therefore, our results strongly suggest that the immune-modulatory functions of OSCC can be uniquely regulated according to their malignant stages. In the early stage, mesenchymal stromal cells (i.e., $\mathrm{CAF}$ ) could be a unique effector. Humoral factor(s) from OSCC cells force CAF to exert immune suppression via the direct cell contacts to effector T cells [15].

In this report, we attempted to isolate the humoral factor(s) secreted by OSCC cells in order to potentiate CAF-mediated immune suppression that enables the progression of OSCC.

\section{MATERIALS AND METHODS}

\subsection{Experimental Animals}

Twenty-four-week-old male $\mathrm{C} 3 \mathrm{H} / \mathrm{HeN}$ mice were pur-

\footnotetext{
* Address correspondence to this author at the Department of Oral Biochemistry, Asahi University School of Dentistry, 1851-1 Hozumi, Mizuho, Gifu, 501-0296, Japan. Phone: +81-058-329-1416; Fax: +81-058-329-1417;

E-mail: nkondoh@dent.asahi-u.ac.jp
}

chased from Chubu Kagaku Shizai Co., Ltd. (Nagoya, Japan) and maintained ad libitum on Oriental MF solid chow (Oriental Yeast Co., Tokyo, Japan).

\subsection{OSCC Cells and Sub-Clones}

The C3H mouse OSCC cell line, Sq-1979, and C3H mouse embryotic fibroblasts, 10T1/2 cells, were obtained from the RIKEN BioResource Center (Ibaraki, Japan). Sq-1979 cells were grown in Eagle's minimum essential medium (E-MEM; Wako, Osaka, Japan) supplemented with $10 \%$ fetal bovine serum (FBS, NICHIREI BIOSCIENCES INC., Tokyo, Japan) and $1 \%$ Pen Strep (penicillin 10,000 unit $/ \mathrm{mL}$, streptomycin $10,000 \mu \mathrm{g} / \mathrm{mL} ; \quad$ Gibco ${ }$, Life Technologies, Grand Island,NY,USA). 10T1/2 cells were grown in Basal Medium Eagle (BME; Gibco ${ }^{\circledR}$, Life Technologies) supplemented with $10 \%$ FBS (NICHIREI BIOSCIENCES INC.) and 1\% Pen Strep (Gibcoß, Life Technologies). Establishments of L cells including L5-11, a metastatic Sq-1979 sub-clone established from the tumor-implanted mice, were described [17].

\subsection{RNA Extraction and Microarray Analysis}

RNA extractions were performed using ISOGEN (Nippon Gene, Tokyo, Japan), according to the manufacturer's instructions. Total RNAs were extracted from Sq-1979 and L5-11 cells. cDNA microarray analysis was performed (Oncomics, Nagoya, Japan) using the Superscript G3 mouse GE Microarray 60K kit (Agilent, Santa Clara, CA, USA). To ensure the reliability of the data, genes were considered to be differentially expressed if the $P$-values were $<0.001$ (Student $t$ test) and had a fold change $>2.0$.

\subsection{Reverse Transcription-Quantitative Polymerase Chain Reaction (RT-qPCR).}

Whole-cell RNA extraction and quantitative PCR was performed as previously described [13]. Primer sequences were designed by Primer Express software (version 2; Applied Biosystems; Thermo Fisher Scientific, Inc., Waltham, MA, USA). Primer sequences were as follows: $C c l 2$, forward 5'AAA AAC CTGG ATC GGA ACC AAA TG-3' and reverse 5'-TGC TTG AGG TGG TTG TGG AAA AG-3'; Ccl7, forward 5'- TGC TCA TAG CCG CTG CTT TCA G-3' and reverse 5'- GCT TCC CAG GGA CAC CGA CTA C-3'; Ill $\alpha$, forward 5'- TTT GAC ATG TAT GCC TAC TCG TCG G-3' and reverse 5'- CTG TGA TGA GTT TTG GTG TTT CTG GC-3'; Illf6, forward 5'- AAG AAC TAA GGC TGC TCT GGC TTT CC-3' and reverse 5'- TGC CAT GGT CCT TAT CTC TCA ATG A-3'; Il6, forward 5'- CCT ACC CCA ATT TCC AAT GCT CTC-3' and reverse 5'- GCA TAA CGC ACT AGG TTT GCC G-3'; ribosomal protein S5 (RPS5), forward 5'- AGA AGA CTC AAC ACG CAT TGG GC -3' and reverse 5'- GCA CTC AGC GAT GGT CTT GAT GT -3'. Each expression level of mRNA was normalized to RPS5.

\subsection{Preparation of Mouse Spleen Cells}

Spleens were removed from more than twenty four-weekold male $\mathrm{C} 3 \mathrm{H} / \mathrm{HeN}$ mice, with the spleen cells isolated as described [18]. Briefly, the spleen tissue was mashed with a stainless steel mesh in Roswell Park Memorial Institute 
(RPMI) 1640 medium (Sigma-Aldrich, St. Louis, MO) containing 10\% FBS (NICHIREI BIOSCIENCES INC.), 50 $\mu \mathrm{M}$ 2-mercaptoethanol (Nacalai Tesque, Kyoto, Japan) and 1\% antibiotic antimycotic solution (penicillin 10,000 unit/mL, streptomycin 10,000 $\mu \mathrm{g} / \mathrm{mL}$, amphotericin B $25 \mu \mathrm{g} / \mathrm{mL}$; Gibco ${ }^{\circledR}$, Life Technologies). Cells were collected by centrifugation at 1,500 rpm for $5 \mathrm{~min}$, and then red blood cells in the collected cells were removed using a red blood cell lysis buffer (10 mM Tris-HCl (pH7.3) containing $140 \mathrm{mM} \mathrm{NH}_{4} \mathrm{Cl}$ and $1 \mathrm{mM} \mathrm{Na} \mathrm{Na}_{2}$ EDA). The spleen cells were washed and resuspended with the RPMI-1640 medium and filtered using a cell strainer (Falcon ${ }^{\circledR}$, Corning Inc., NY, USA) to remove the residue.

\subsection{OSCC Cell-Conditioned Medium}

To confirm humoral factor(s) from Sq-1979 cells, conditioned medium (CM) was prepared from cultured Sq-1979 cells. One million Sq-1979 cells were cultured in 10 $\mathrm{mL}$ of RPM-I1640 medium supplemented in $5 \% \mathrm{CO}_{2}$ at $37^{\circ} \mathrm{C}$. The CM was collected after $36 \mathrm{~h}$ by centrifugation at 1,000 rpm for 5 min. As a control, RPMI medium was denoted as untreated medium (UM). The concentration of IL- $1 \alpha$ in the CM was assayed by sandwich ELISA using Mouse IL-1 $\alpha /$ IL-1F1 Quantikine ELISA Kit (R\&D Systems Inc., Minneapolis, MN, USA). For standardization, a calibration curve against recombinant mouse IL-1 $\alpha$ was run with each assay. Finally, in order to absorb specific cytokines, CM was pre-treated with various combinations of $1 \mu \mathrm{g} / \mathrm{ml}$ mouse anti CCL2 (AF-479NA), CCL7 (AF-456-NA), IL-1 $\alpha$ (AF-400-NA), IL-6 (AF-406NA) and IL-1F6 (AF2296) antibodies (R\&D systems) at $4^{\circ} \mathrm{C}$ for $8 \mathrm{~h}$. To confirm cytokine activity, recombinant mouse IL-1 $\alpha$ (400-ML-005, R\&D systems) was used.

\subsection{Analysis of IFN- $\gamma$ Production from Spleen Cells which were Co-Cultured with $\mathrm{CM}$ and/or 10T1/2 Cells}

The spleen cell suspension $\left(4 \times 10^{5} /\right.$ well $)$ was added to a 96-well plate (3599, Corning), on which $1 \mu \mathrm{g} / \mathrm{mL}$ of anti-CD3 monoclonal antibody (mAb) (145-2C12 BD Biosciences, San Diego, CA, USA) had been immobilized $(0.1 \mathrm{~mL} /$ well $)$ at $4{ }^{\circ} \mathrm{C}$ overnight. Then, $\mathrm{CM}$ (diluted to $50 \%$ in the final culture medium) and/or $10 \mathrm{~T} 1 / 2$ cells $\left(3 \times 10^{3} /\right.$ well $)$ were added to the wells and co-cultured with the spleen cells in the RPMI 1640 basal medium supplemented with $10 \%$ FBS for $48 \mathrm{~h}$ in $5 \% \mathrm{CO}_{2}$ at $37^{\circ} \mathrm{C}$. After that, the supernatant was harvested by centrifugation at $3,000 \mathrm{rpm}$ for $5 \mathrm{~min}$ and stored at $-80^{\circ} \mathrm{C}$.

The concentration of IFN- $\gamma$ in the supernatant of the cell culture was assayed by sandwich ELISA using BD OptE1A set (BD Biosciences). For standardization, a calibration curve against re-combinant mouse IFN- $\gamma$ was run with each assay.

In each experiment, stimulated spleen cells were cultured without $10 \mathrm{~T} 1 / 2$ in $\mathrm{UM}$ as a control. For intra-examiner agreement, the values of the control culture were checked and were within the specified range $(300 \sim 500 \mathrm{ng} / \mathrm{mL} \mathrm{IFN- \gamma}$ produced).

\subsection{Western Blot Analysis}

Cells were scraped with a rubber policeman and collected in $10 \times$ cell lysis buffer (Cell Signaling Technology, Beverly, MA, USA). A solution containing phenylmethanesulfonyl fluoride $(1 \mathrm{mM})$ plus one tablet of protease inhibitor cocktail (Complete, EDTA-free; Roche Diagnostics GmbH, Mannheim, Germany) was added to each cell lysate. Protein contents in the lysates were assayed, and equal amounts of protein for each sample were subjected to $15 \%$ SDS-polyacrylamide gel electrophoresis, followed by immunoblotting with primary antibodies against anti-IL-1 $\alpha$ rabbit polyclonal antibody (ab9724) (Abcam PLC, Cambridge, UK, 1:1,000) and anti- $\beta$ actin antibody (Sigma-Aldrich, St.Louis, Mo, USA, 1:10,000). Signals were detected using the corresponding peroxidaseconjugated secondary antibodies (anti-rabbit IgG or anti-mouse IgG; Cell Signaling Technology and used at a concentration of $1: 10,000)$, and immunoreactive bands were visualized by chemiluminescence (Clarity ${ }^{\mathrm{TM}}$ Western ECL substrate; BioRad, Hercules, CA, USA). The membranes and images were developed with an ImageQuant ${ }^{\mathbf{T M}}$ LAS500 Imaging System (GE Healthcare Bio-Sciences AB, Uppsala, Sweden).

\subsection{Statistics}

Data are expressed as means \pm Standard Deviation (SD). For ELISA, Student's $t$-test was applied to determine the significance of differences between the two groups. $P<0.01$ was considered to be statistically significant.

\section{RESULTS}

\subsection{Isolation of Cytokine mRNAs Predominantly Expressed in Sq-1979 Cells.}

The results of our previous study suggest that humoral factor(s) secreted from Sq-1979 cells could specifically transmit a suppressive function against the IFN- $\gamma$-producing capability of antigen-stimulated spleen cells in co-culture with $10 \mathrm{~T} 1 / 2$ cells. By contrast, the activity of the stimulated spleen cells was not reduced in the co-culture containing L cells, a metastatic Sq-1979 cell variant [15]. Therefore, the suppressive activity of $10 \mathrm{~T} 1 / 2$ cells was specifically enhanced by humoral factor(s) generated by Sq-1979 cells but not by L cells. In order to identify cytokine mRNAs specifically expressed in Sq-1979 cells, cDNA micro array analysis was performed between mRNAs from Sq-1979 and L5-11 cells. We eventually focused on the 5 mRNAs $I l 1-\alpha, I l 1 f 6, I l 6, C c l 2$ and $C c l 7$. As shown in Fig. (1), the expression of these mRNAs was predominantly elevated in Sq-1979 rather than in L5-11 cells.

\subsection{Blocking Immunosuppressive Function of CM by Neutralizing Antibodies against Cytokines.}

As shown in Fig. (2A), the IFN- $\gamma$-producing capability of the stimulated spleen cells (lane $1,10 \mathrm{~T} 1 / 2(-)$ ) was significantly reduced in the presence of directly contacted 10T1/2 cells (lane $1,10 \mathrm{~T} 1 / 2(+))$, with further reductions caused by the addition of Sq-1979 conditioned medium (CM) (lane 2 of $10 \mathrm{~T} 1 / 2(+)$ ). The capability of $\mathrm{CM}$ to reduce IFN- $\gamma$ production was negated by 


\section{Ccl2}

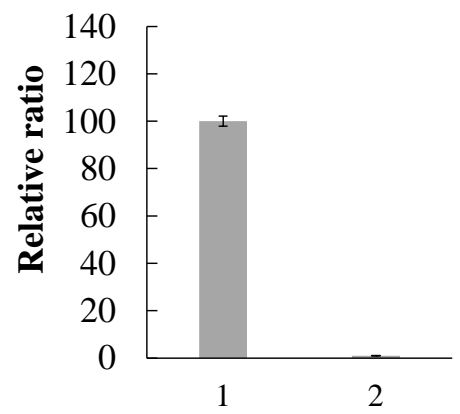

Illf6

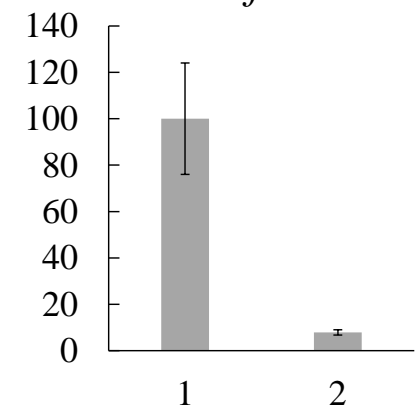

Ccl7

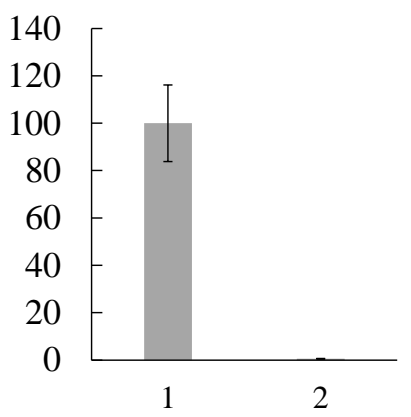

Il6

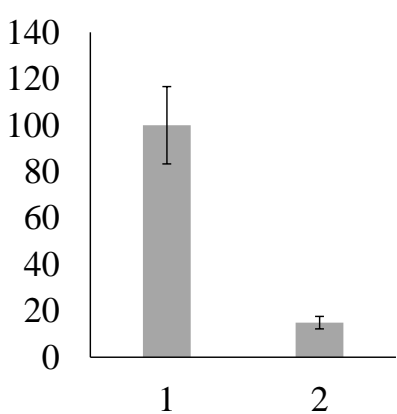

$\operatorname{Ill} \alpha$

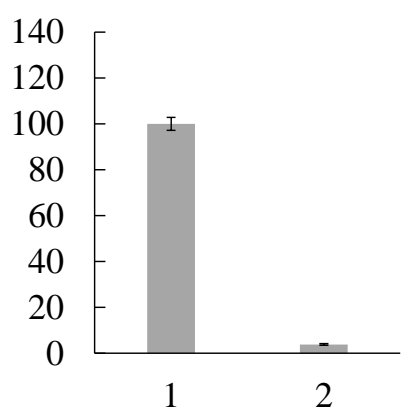

1. Sq-1979 cells

2. L5-11 cells

Fig. (1). Comparison of differentially expressed cytokine mRNAs between Sq-1979 (lane 1) and L5-11 (lane 2) cells. Relative expression levels (\%) are in ordinate. $* 0.01>\mathrm{P}$.

absorbing the CM with anti-IL-1 $\alpha$ antibody (ab) (lane 4 of $10 \mathrm{~T} 1 / 2(+))$. However, it remained unchanged when absorbed by anti-CCL2, CCL7, IL-1f6 and IL-6 abs (lanes 5, 6, 7 and 8 of $10 \mathrm{~T} 1 / 2(+))$, or by the addition of IgG, as a control antibody (lane 3 of 10T1/2(+)). On the other hand, in the absence of $10 \mathrm{~T} 1 / 2$ cells, IFN- $\gamma$-producing capability was not reduced by treating the cells with CM (lane 2 of $10 \mathrm{~T} 1 / 2(-))$ or any of its absorbed variants (lanes 1 through 8 of 10T1/2(-)).

As shown in Fig. (2B), the ratio of IFN- $\gamma$-producing capability was reduced to almost $60 \%$ in the presence of $10 \mathrm{~T} 1 / 2$ cells (lane 1 ), and further reduced to less than $40 \%$ by adding CM (lane 2). This CM mediated reduction was completely negated by absorbing the CM with anti-IL-1 $\alpha$ ab (lane 4). However, it remained unchanged when absorbing the CM with anti-CCL2, anti-CCL7, anti-IL-1f6, or anti-IL-6 abs (lanes 5-8, respectively). The CM mediated reduction was also unchanged by the addition of control IgG (lane 3).

\subsection{Promotion of Immunosuppressive Activity of $10 \mathrm{~T} 1 / 2$ by IL-1a}

We examined the expression of IL- $1 \alpha$ protein in OSCC cells. As shown in Fig. (3A), Sq-1979 cells expressed significantly high levels of IL- $1 \alpha$, while the expression was scarcely detectable in L5-11 cells. Using ELISA, we also found that the concentration of IL- $1 \alpha$ in CM of Sq1979 cells was 52.5 $\pm 1.3 \mathrm{pg} / \mathrm{ml}(\mathrm{n}=3)$. Thus, we concluded that IL-1 $\alpha$ was specifically produced and secreted in the CM by Sq-1979 cells. In order to examine the functional significance of the IL- $1 \alpha$ in $\mathrm{CM}$, recombinant IL-1 $\alpha$ was mixed with UM, then added to the co-culture of stimulated spleen cells and 10T1/2 cells. As shown in Fig. (3B), the reduced IFN- $\gamma$-producing capability of the stimulated spleen cells in the presence of 10T1/2 cells (lane 1 vs lane 2) was further reduced by adding $50 \mathrm{pg} / \mathrm{ml}$ of IL- $1 \alpha$ (lane 3 with 10T1/2 cells). The mediated reduction of IFN- $\gamma$ production by UM containing recombinant IL- $1 \alpha$ was comparable to that by CM. However, it is notable that further reduction of the IFN- $\gamma$ level was not observed when increased concentrations of IL-1 $\alpha$ (150 pg/micro 1) were used, suggesting that Sq-1979 cells produce significant amount of IL-1 $\alpha$ for this activity (lane 4 with $10 \mathrm{~T} 1 / 2$ cells). Immunosuppressive function mediated by CM and IL- $1 \alpha$ was not observed in the absence of $10 \mathrm{~T} 1 / 2$ cells.

\section{DISCUSSION}

IL- $1 \alpha$ is a unique cytokine possessing the dual function of binding to chromatin to regulate transcription as well as to cell surface receptors as a signaling molecule [19]. IL-1 $\alpha$ is rarely secreted by living cells and in most cases is undetectable in body fluids [20]. Keratinocyte-derived IL- $1 \alpha$ induces woundinduced papilloma formation [21]. In skin homeostasis, epidermal tissue regeneration is mainly regulated by keratinocyte -derived IL-1 signaling, which induces keratinocyte growth factor expression in skin fibroblasts [22].

Tumor cell derived IL- $1 \alpha$ preferentially activates antitumor immunity. Membrane-associated IL- $1 \alpha$ may thus serve as an adhesion molecule. Constitutive expression of membrane -associated (but not secreted) IL- $1 \alpha$ by oncogene-transformed fibrosarcoma cells induced regression of tumors in mice by activating $\mathrm{CD} 8^{+} \mathrm{T}$ cells [23]. IL-1 $\alpha$ production induced by cytokines/immunomodulators in $\mathrm{T}$ cell lymphoma cells also causes the stimulation of antitumor immune responses [24]. 

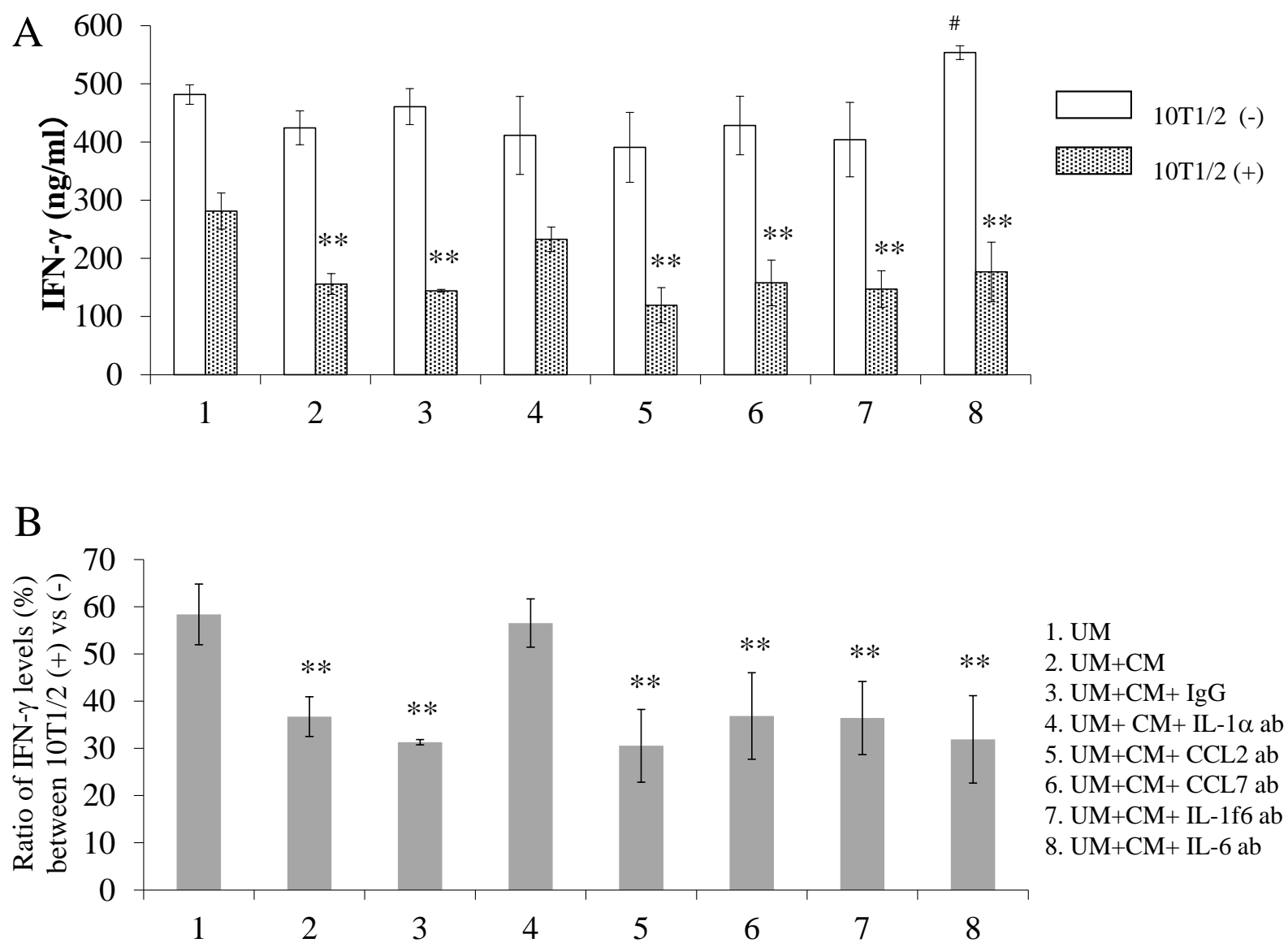

Fig. (2). (A) IFN- $\gamma$-producing capability of stimulated spleen cells treated with CM in the absence (-) or presence (+) of 10T1/2 cells. Cells were cocultured in; UM (RPMI medium supplemented with 10\% FBS) (paired lanes 1); UM mixed in a 1/1 ratio with CM (paired lanes 2); UM mixed with the CM containing 1 micro $\mathrm{g} / \mathrm{ml}$ of IgG as a control (paired lanes 3); UM mixed with the CM containing anti IL-1 $\alpha$ ab, anti CCL2 ab, anti CCL7 ab, anti IL-1f6 ab and anti IL-6 ab (paired lanes 4 to 8, respectively). (B) Ratios of IFN- $\gamma$-producing capability $(\%)$ in the presence (+) against that in the absence (-) of 10T1/2 cells. Lanes correspond to paired lanes in (Fig. 2A). *,* $0.01>$ P.

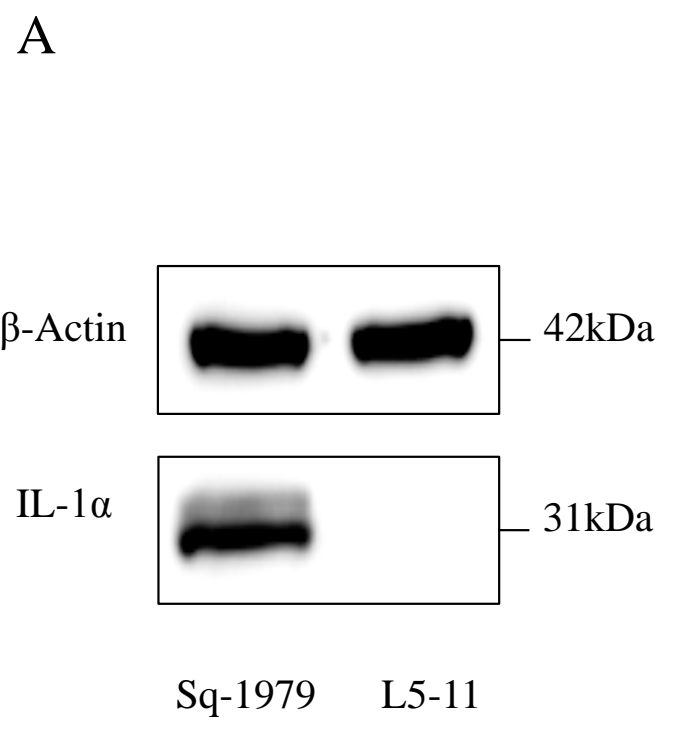

\section{B}

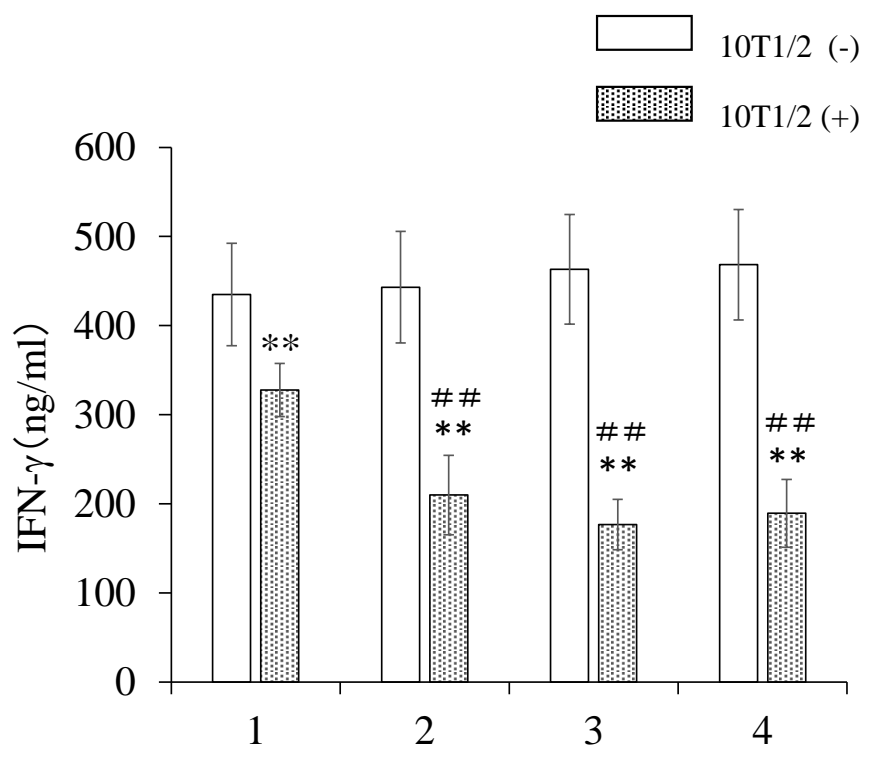

Fig. (3). (A) Expression of IL-1 $\alpha$ protein in Sq-1979 and L5-11 cells. (B) IFN- $\gamma$-producing capability of stimulated spleen cells treated with UM, UM mixed in a $1 / 1$ ratio with $\mathrm{CM}$, UM containing $50 \mathrm{pg} / \mathrm{ml}$ of IL-1a, UM containing $150 \mathrm{pg} / \mathrm{ml}$ of IL- $1 \alpha$ (paired lanes 1 to 4 , respectively), in the presence $(+)$ or absence $(-)$ of $10 \mathrm{~T} 1 / 2$ cells. $* 0.01>\mathrm{P}$. 
By contrast, protumoral (namely immunosuppressive) activity of IL-1 $\alpha$ has been reported in tumor-stromal crosstalk. In OSCC tissues, IL- $1 \alpha$ affects CAF to produce CCL7, CXCL1 and IL-8, which promote motility and invasion of tumor cells $[25,26]$. Immunosuppressive function of IL- $1 \alpha$ via CAF has been reported in the tumor milieu of melanomas harboring BRAF (V600E) oncogene, by which the expression of IL- $1 \alpha$ is specifically activated [27]. In the prostatic carcinoma tissue, IL- $1 \alpha$ upregulates TGF- $\beta$ production from mesenchymal stem cells (MSCs), resulting in the potential suppression of immune cells and the promotion of tumor cells [28]. Our present results first demonstrate the immunosuppressive activity of IL- $1 \alpha$ in OSCC cells. The reduced production of IFN- $\gamma$ from antigenstimulated spleen cells, attributable to direct contact with mesenchymal $(10 \mathrm{~T} 1 / 2)$ cells was further reduced in the presence of IL-1 $\alpha$. Sq-1979 cells produced significant amount of IL- $1 \alpha$ for this immunesuppression. The production of IL-1 $\alpha$ is specifically elevated in Sq-1979 cells, however it is undetectable in L5-11 cells, one of the metastasized sub-clones of Sq1979 cells. The inability of L5-11 cells to enhance the immunosuppressive function of $10 \mathrm{~T} 1 / 2$ cells has been confirmed [15]. We have already reported, the immunosuppressive efficacy of the OSCC milieu is developed in a stepwise manner depending on the stages of OSCCs $[14,16]$. Therefore, in the early stage OSCC as represented by Sq-1979 cells, IL-1 $\alpha$ from the tumor cells could functionally promote mesenchymal stromal cells as a unique effector exerting immune suppression via direct cell contact with activated $\mathrm{T}$ cells. These, however, do not induce any MDSCs in the tumorbearing mice [16].

Our observations suggest that IL-1 $\alpha$ may specifically contribute to the development of OSCC in early stages. In fact, IL-1 receptor antagonist (IL1RN) is significantly down regulated in early OSCCs compared to premalignant lesions and advanced OSCCs [29]. In head and neck SCC patients, significant correlation between IL- $1 \alpha$ expression and development of distance metastasis has been reported [30]. The mechanism by which OSCCs differentially utilize immune modulatory aspects involving CAFs, MDSCs and several other factors is not fully understood. Among these aspects, the function of IL-1 $\alpha$ seems to be pleiotropic depending on the tumor cell types. In melanoma tissues, immunosuppressive function of IL-1 $\alpha$ is, in part, mediated by upregulation of programmed cell death ligand (PD-L) 1 and PD-L2 mRNAs in CAFs [27]. The inflammatory responses that result from periodontitis cause several miRNAs to exert control over all aspects of innate and adaptive immunity [31]. Furthermore, high level miR-197 expression is closely correlated with poor overall survival and reduced PD-L1 transcription in OSCC tissues [32]. However, in our observation, both PD-L1 and PDL2 mRNAs were unchanged or undetectable in IL-1 $\alpha$-treated 10T1/2 cells, respectively (unpublished data).

\section{CONCLUSION}

In conclusion, IL- $1 \alpha$ could be a promoter of motility, invasion and immune suppression in OSCC tissues. Further elucidation of the regulatory pathways involving IL- $1 \alpha$ could identify important therapeutic targets in OSCC development.

\section{ETHICS APPROVAL AND CONSENT TO PARTICIPATE}

This study was approved by the Animal Ethics Committee of Asahi University (No. 17-038),

\section{HUMAN AND ANIMAL RIGHTS}

No humans were used for studies that are the basis of this research. All animal experiments were conducted according to American Veterinary Medical Association (AVMA) Guidelines for the Euthanasia of Animals: 2013 Edition

\section{CONSENT FOR PUBLICATION}

Not applicable.

\section{AVAILABILITY OF DATA AND MATERIALS}

The data sets analyzed during the current study are available from the corresponding author on request.

\section{FUNDING}

This work was financially supported in part by the Grantsin-Aid for Scientific Research from the Japan Society for the Promotion of Science KAKENHI Grant Number (JP17K11891).

\section{CONFLICT OF INTEREST}

The authors declare no conflict of interest, financial or otherwise.

\section{ACKNOWLEDGEMENTS}

Declared none.

\section{SUPPLEMENTARY MATERIAL}

Supplementary material is available on the publishers web site along with the published article.

\section{REFERENCES}

[1] Gao W, Guo CB. Factors related to delay in diagnosis of oral squamous cell carcinoma. J Oral Maxillofac Surg 2009; 67(5): 1015-20.

[http://dx.doi.org/10.1016/j.joms.2008.12.022] [PMID: 19375011]

[2] McDowell L, Collins M, Kleid S, Rischin D, Corry J. T4 squamous cell carcinoma of the oral tongue without mandibular involvement: Surgery or chemoradiotherapy? Oral Surg Oral Med Oral Pathol Oral Radiol 2014; 117(2): 163-9.

[http://dx.doi.org/10.1016/j.oooo.2013.09.005] [PMID: 24275355]

[3] Shinriki S, Jono H, Maeshiro M, et al. Loss of CYLD promotes cell invasion via ALK5 stabilization in oral squamous cell carcinoma. J Pathol 2018; 244(3): 367-79.

[http://dx.doi.org/10.1002/path.5019] [PMID: 29235674]

[4] Inaba H, Sugita H, Kuboniwa M, et al. Porphyromonas gingivalis promotes invasion of oral squamous cell carcinoma through induction of proMMP9 and its activation. Cell Microbiol 2014; 16(1): 131-45. [http://dx.doi.org/10.1111/cmi.12211] [PMID: 23991831]

[5] Ai R, Tao Y, Hao Y, et al. Microenvironmental regulation of the progression of oral potentially malignant disorders towards malignancy. Oncotarget 2017; 8(46): 81617-35.

[http://dx.doi.org/10.18632/oncotarget.20312] [PMID: 29113419]

[6] Kondoh N, Mizuno-Kamiya M, Takayama E, et al. Perspectives of immune suppression in the tumor microenvironment. Open Dent $\mathrm{J}$ 2018; 12: 455-65.

[http://dx.doi.org/10.2174/1874210601812010455] [PMID: 29988281]

[7] Wu AA, Drake V, Huang HS, Chiu S, Zheng L. Reprogramming the tumor microenvironment: Tumor-induced immunosuppressive factors 
paralyze T cells. OncoImmunology 2015; 4(7)e1016700 [http://dx.doi.org/10.1080/2162402X.2015.1016700] [PMID: 26140 242]

[8] Takahashi H, Sakakura K, Kawabata-Iwakawa $\mathrm{R}$, et al. Immunosuppressive activity of cancer-associated fibroblasts in head and neck squamous cell carcinoma. Cancer Immunol Immunother 2015; 64(11): 1407-17.

[http://dx.doi.org/10.1007/s00262-015-1742-0] [PMID: 26201938]

[9] Takahashi H, Sakakura K, Kudo T, et al. Cancer-associated fibroblasts promote an immunosuppressive microenvironment through the induction and accumulation of protumoral macrophages. Oncotarget 2017; 8(5): 8633-47.

[http://dx.doi.org/10.18632/oncotarget.14374] [PMID: 28052009]

[10] Fujii N, Shomori K, Shiomi T, et al. Cancer-associated fibroblasts and CD163-positive macrophages in oral squamous cell carcinoma: Their clinicopathological and prognostic significance. J Oral Pathol Med 2012; 41(6): 444-51.

[http://dx.doi.org/10.1111/j.1600-0714.2012.01127.x] [PMID: 22296 275]

[11] Arantes DA, Costa NL, Mendonça EF, Silva TA, Batista AC. Overexpression of immunosuppressive cytokines is associated with poorer clinical stage of oral squamous cell carcinoma. Arch Oral Biol 2016; 61: 28-35.

[http://dx.doi.org/10.1016/j.archoralbio.2015.10.013] [PMID: 26513 679]

[12] Mace TA, Ameen Z, Collins A, et al. Pancreatic cancer-associated stellate cells promote differentiation of myeloid-derived suppressor cells in a STAT3-dependent manner. Cancer Res 2013; 73(10): 3007-18.

[http://dx.doi.org/10.1158/0008-5472.CAN-12-4601] [PMID: 23514 705]

[13] Galon J, Pagès F, Marincola FM, et al. Cancer classification using the Immunoscore: A worldwide task force. J Transl Med 2012; 10: 205. [http://dx.doi.org/10.1186/1479-5876-10-205] [PMID: 23034130]

[14] Azuma Y, Mizuno-Kamiya M, Takayama E, et al. The producing capabilities of interferon- $\gamma$ and interleukin-10 in primary and metastasized oral squamous cell carcinoma cells. Cancer Transl Med 2017; 3(6): 194-9.

[http://dx.doi.org/10.4103/ctm.ctm_30_17]

[15] Inagaki T, Mizunno-Kamiya M, Takayama E, et al. Suppressive effect of mesenchymal stromal cells on interferon- $\gamma$-producing capability of spleen cells was specifically enhanced via humoral mediator(s) from mouse oral squamous cell carcinoma Sq-1979 cells in vitro. Cancer Transl Med 2018; 4(1): 9-16.

[http://dx.doi.org/10.4103/ctm.ctm_34_17]

[16] Sumi S, Umemura N, Takayama E, et al. Metastasized murine oral squamous cell carcinoma cells induce intratumoral polymorphonuclear myeloid derived suppressor cells. Oncol Rep 2017; 37(5): 2897-904. [http://dx.doi.org/10.3892/or.2017.5575] [PMID: 28405677]

[17] Adachi M, Mizuno-Kamiya M, Takayama E, et al. Gene expression analyses associated with malignant phenotypes of metastatic subclones derived from a mouse oral squamous cell carcinoma Sq-1979 cell line. Oncol Lett 2018; 15(3): 3350-6. [PMID: 29435078]

[18] Nagaya R, Mizuno-Kamiya M, Takayama E, et al. Mechanisms of the immunosuppressive effects of mouse adipose tissue-derived mesenchymal stromal cells on mouse alloreactively stimulated spleen cells. Exp Ther Med 2014; 7(1): 17-22.

[http://dx.doi.org/10.3892/etm.2013.1382] [PMID: 24348 757]

[19] Rider P, Carmi Y, Voronov E, Apte RN. Interleukin-1 $\alpha$. Semin Immunol 2013; 25(6): 430-8. [http://dx.doi.org/10.1016/j.smim.2013.10.005] [PMID: 24183701]

[20] Hacham M, Argov S, White RM, Segal S, Apte RN. Different patterns of interleukin-1alpha and interleukin-1beta expression in organs of normal young and old mice. Eur Cytokine Netw 2002; 13(1): 55-65. [PMID: 11956021]

[21] Arwert EN, Lal R, Quist S, Rosewell I, van Rooijen N, Watt FM. Tumor formation initiated by nondividing epidermal cells via an inflammatory infiltrate. Proc Natl Acad Sci USA 2010; 107(46): 19903-8.

[http://dx.doi.org/10.1073/pnas.1007404107] [PMID: 21041641]

[22] Maas-Szabowski N, Stark HJ, Fusenig NE. Keratinocyte growth regulation in defined organotypic cultures through IL-1-induced keratinocyte growth factor expression in resting fibroblasts. J Invest Dermatol 2000; 114(6): 1075-84.

[http://dx.doi.org/10.1046/j.1523-1747.2000.00987.x] [PMID: 10844 548]

[23] Dvorkin T, Song X, Argov S, et al. Immune phenomena involved in the in vivo regression of fibrosarcoma cells expressing cell-associated IL-1alpha. J Leukoc Biol 2006; 80(1): 96-106. [http://dx.doi.org/10.1189/jlb.0905509] [PMID: 16707560]

[24] Voronov E, Weinstein Y, Benharroch D, et al. Antitumor and immunotherapeutic effects of activated invasive T lymphoma cells that display short-term interleukin 1alpha expression. Cancer Res 1999; 59(5): 1029-35.

[PMID: 10070959]

[25] Bae JY, Kim EK, Yang DH, et al. Reciprocal interaction between carcinoma-associated fibroblasts and squamous carcinoma cells through interleukin- $1 \alpha$ induces cancer progression. Neoplasia 2014; 16(11): 928-38.

[http://dx.doi.org/10.1016/j.neo.2014.09.003] [PMID: 25425967]

[26] Jung DW, Che ZM, Kim J, et al. Tumor-stromal crosstalk in invasion of oral squamous cell carcinoma: A pivotal role of CCL7. Int J Cancer 2010; 127(2): 332-44.

[http://dx.doi.org/10.1002/ijc.25060] [PMID: 19937793]

[27] Khalili JS, Liu S, Rodríguez-Cruz TG, et al. Oncogenic BRAF(V600E) promotes stromal cell-mediated immunosuppression via induction of interleukin-1 in melanoma. Clin Cancer Res 2012; 18(19): 5329-40.

[http://dx.doi.org/10.1158/1078-0432.CCR-12-1632] [PMID: 22850 568]

[28] Cheng J, Li L, Liu Y, Wang Z, Zhu X, Bai X. Interleukin-1 $\alpha$ induces immunosuppression by mesenchymal stem cells promoting the growth of prostate cancer cells. Mol Med Rep 2012; 6(5): 955-60.

[http://dx.doi.org/10.3892/mmr.2012.1019] [PMID: 22895682]

[29] Shiiba M, Saito K, Yamagami H, et al. Interleukin-1 receptor antagonist (IL1RN) is associated with suppression of early carcinogenic events in human oral malignancies. Int J Oncol 2015; 46(5): 1978-84

[http://dx.doi.org/10.3892/ijo.2015.2917] [PMID: 25738940]

[30] León X, Bothe C, García J, et al. Expression of IL-1 $\alpha$ correlates with distant metastasis in patients with head and neck squamous cell carcinoma. Oncotarget 2015; 6(35): 37398-409.

[http://dx.doi.org/10.18632/oncotarget.6054] [PMID: 26460957]

[31] Luan X, Zhou X, Naqvi A, et al. MicroRNAs and immunity in periodontal health and disease. Int J Oral Sci 2018; 10(3): 24. [http://dx.doi.org/10.1038/s41368-018-0025-y] [PMID: 30078842]

[32] Ahn H, Yang JM, Kim H, et al. Clinicopathologic implications of the miR-197/PD-L1 axis in oral squamous cell carcinoma. Oncotarget 2017; 8(39): 66178-94.

[http://dx.doi.org/10.18632/oncotarget.19842] [PMID: 29029502]

(C) 2019 Morimoto-Ito et al.

This is an open access article distributed under the terms of the Creative Commons Attribution 4.0 International Public License (CC-BY 4.0), a copy of which is available at: (https://creativecommons.org/licenses/by/4.0/legalcode). This license permits unrestricted use, distribution, and reproduction in any medium, provided the original author and source are credited. 